\title{
Technology Regeneration Guided with Fibrin Rica in Platelets in Implantodontia - A Literature Review
}

\author{
Linda Gabriele Gomes Cerqueira, B. Sc \\ Adriana Vanderlei do Amorim, M. Sc. \\ UNIFTC - Victory of the Conquest, Brazil
}

Doi:10.19044/esj.2021.v17n34p252

Submitted: 10 September 2021

Accepted: 27 September 2021

Published: 30 September 2021
Copyright 2021 Author(s)

Under Creative Commons BY-NC-ND

4.0 OPEN ACCESS

Cite As:

Gomes Cerqueira L.G. \& Vanderlei do Amorim A. (2021). Technology Regeneration Guided with Fibrin Rica in Platelets in Implantodontia - A Literature Review. European Scientific Journal, ESJ, 17(34), 252.

https://doi.org/10.19044/esj.2021.v17n34p252

\section{Abstract}

The tissue loss is one of the consequences of damage caused by tooth loss and consequently bone tissue, one of the techniques to minimize or even correct this damage is the use of platelet-rich fibrin-guided tissue regeneration. The use of biomaterials in order to replace bone deficiencies in the regions to be implanted should provide the capacity to regenerate bone tissue, as well as make the new bone structures functional. A bibliographic survey of articles published between 2013 and 2021, articles indexed in the Databases PubMed/MEDLINE, Scielo and Google Scholar, was carried out using the keywords "Fibrin-rich platelets", "Periodontics", "Connective Tissue" and "Guided Tissue Regeneration". We found 206 articles published in the specified period, after reading the title and abstract, 17 potential articles were identified to be part of the literature review. The technique of using plateletrich fibrin in dentistry has shown promising results, with low cost, easy execution and accelerated healing process. The limitations of the technique were found the short time to use the material and the small amount obtained after centrifugation.

Keywords: Gingiva, Periodontics, Connective Tissue, Wound Healing, Platelet-Rich Fibrin 


\section{Introduction}

The tissue loss is one of the consequences of damage caused by tooth loss and consequently bone tissue, one of the techniques to minimize or even correct this damage is the use of platelet-rich fibrin-guided tissue regeneration. The edge atrophy is usually associated with difficulties in the installation of conventional prostheses(Carla \& Fria, 2018). Thus, alveolar edge atrophy is a clinical condition that requires a series of care and procedures aimed at increasing the potential for tissue gain in affected regions (Gama Aires et al., 2020).

The use of biomaterials in order to replace bone deficiencies in the regions to be implanted should provide the capacity to regenerate bone tissue, as well as make the new bone structures functional (Fursel et al., 2021). Platelet-rich fibrin (PRF) is part of the second generation of platelet concentrates and has been clinically used with the intention of accelerating tissue repair (Hak, 2020). It is obtained from a blood sample, from the patient himself, without the addition of any anticoagulants or activators such as heparin, and taken to centrifugation, with different protocols, to obtain byproducts with different indications of useful applications to improve healing and promote tissue regeneration (Fursel et al., 2021; Godoy, 2013; Rodrigues et al., 2015; Seidler, 2019).

The research using PRF membranes has indicated the acceleration of bone and soft tissue regeneration processes, as well as their application in reconstructive surgeries (Gama Aires et al., 2020; Rossi, 2019). And for these effects they receive great attention from the scientific world and have been the subject of numerous studies. The studies in this area are fundamental for understanding the biological processes involved and the applicability of this material (Carla \& Fria, 2018; Rossi, 2019).

Thus, the present work aims to identify the feasibility of using this new model of platelet aggregate the PRF, and consider the positive and negative results using this technique, in order to evidence its regenerative characteristics and its method of obtaining.

\section{Methodology of Narrative Literature Review}

A bibliographic survey of articles published between 2013 and 2021, articles indexed in the Databases PubMed/MEDLINE, Scielo and Google Scholar, was carried out using the keywords Fibrin-rich platelets", "Periodontia", "Connective Tissue" and "Guided Tissue Regeneration". Articles published in Portuguese and English were selected in all databases, being used the English language - exclusively in PubMed because it is a data search engine with publications mostly in English. As inclusion criteria, intervention articles were adopted and carried out in humans in order to meet the proposed objective of this literature review. We found 206 articles 
published in the specified period, after reading the title and abstract, 17 potential articles were identified to be part of the literature review. The evaluated articles were selected that reported from healing to bone regeneration by platelet-rich fibrin.

\section{History and Legislation}

The first platelet concentrates to be used and studied in Dentistry in the late 1990s was platelet-rich plasma (PRP) prepared from the individual's own blood and activated by the addition of thrombin and calcium that release growth factors and proteins that can promote faster healing and tissue repair. Periodontal applications of PRP are reported in the treatment of periodontal defects, root covering procedures, edge augmenting graft, guided bone regeneration, breast lift graft and implant surgery(Fursel et al., 2021).

The clinical application of PRP also extends to maxillary and mandibular reconstruction after trauma-related defects, dermal fat grafts, and orthopedic surgery. However, the lack of standardization in the preparation protocol, variation in storage time of different platelet concentrations and the presence of thrombin, causes PRP to result in the development of antibodies that can affect the coagulation process and, consequently, the healing process. Thus, the PRP is questioned in relation to its benefits and clinical results, so that new studies pointed to the use of a new aggregate, the PRF.

Considered as the second generation of platelet aggregates, it is a fully autologous concentrate, which overcomes the limitations of PRP, besides having unlimited availability and regenerative potential with the release of growth factors, in order to promote better and faster healing and repair of surgical lesions. PRF is an autogenous living biomaterial, developed by French physician Choukroun in 2001, and has gained popularity by accelerating the healing of soft and hard tissues. Its advantages over PRP are ease of preparation/application, minimum expense and lack of biochemical modification, as bovine thrombin or anticoagulant is not required (Fursel et al., 2021).

The resolution CFO-158 of June 8, 2015 regulates the use of Autologous Platelet Aggregates for non-transfusion purposes in dentistry, whereas Law No. 5,081 of 08/24/66 that regulates the exercise of dentistry in the country in its article 6 , the following reason that it is incumbent on the dentist: "I - to practice all the acts pertaining to dentistry, arising from knowledge acquired in a regular course or in a postgraduate course;".

The venipuncture is authorized to obtain Autologous Platelet Aggregates for exclusive use in Dentistry by the dentist, duly qualifiedrequires proof of qualification and qualification in venipuncture, and may be presented diplomas, declarations, certificates and congeners - or of a health professional duly qualified together and co-responsible with the dentist. 
The Code of Dental Ethics approved by CFO Resolution 118/2012 regulates the rights and duties of the dentist, technical and auxiliary professionals, and legal entities that perform activities in the area of Dentistry, in the public and/or private sphere, with the obligation to enroll in the Dentistry Councils, according to their specific attributions.

\section{Application and Indication}

The aggregates contain biologically active proteins that bind to a developing fibrin mesh or extracellular matrix. Proteins create a chemotactic gradient for stem cell recruitment. These stem cells undergo differentiation and promote regeneration healing. Thus, the use of autologous platelets opens up a promising treatment option in the field of periodontal regeneration, especially in clinical situations that require rapid results. Platelet-rich fibrin (PRF) is the regeneration material that contains a large amount of growth factors, leukocytes, oxytocin's and collecting, in a single membrane, all the constituents of a blood sample favorable to healing and immunity (Frizzera et al., 2019; Gupta et al., 2019).

\section{Advantage and Disadvantage}

The advantages of PRF as a bioactive substitute include less technical skills in handling, minimal biochemical modification, low effective cost, increased incorporation of circulating cytokines in fibrin meshes and slow polymerization, thus accelerating healing, better structural integrity. It is a promising line of treatment in the sense of tissue regeneration, because, because it is autogenous, PRF decreases the chances of adverse reactions to the implanted material, especially immunomodulated material, as occurs with other types of grafts, which accredits it as a viable option in regenerative procedures. Thus, THE PRF emerged as one of the promising regenerative materials in the field of periodontics(Pontel \& Boabaid, 2019; Zucchelli et al., 2020).

Among the reported limitations of PRF are the low amount that is obtained after centrifugation of the material and the need for use up to 4 hours after preparation, as they may lose structural integrity due to shrinkage due to dehydration. Leukocytes present alter their biological properties and bacterial contamination occurs in storage (Dutta et al., 2019). The PRF preparation protocol is basically the attempt to accumulate platelets and the cytokines released in a fibrin clot (Kumar et al., 2016). Thus, for the preparation of PRF, it is necessary to centrifuge the blood without any addition of anticoagulant and bovine thrombin.

In one of the procurement protocols frequently used in dental offices, the blood sample is taken without anticoagulant in $10 \mathrm{ml}$ tubes (BD Vacutaine Serum) and immediately taken the MontSerrat Analogue bench centrifuge - 
the manufacturer recommends using 1,800 revolutions per minute (rpm) for 10 minutes (figure 1) based on a study by Professor Leonel Alves de Oliveira (Oliveira et al., 2018).

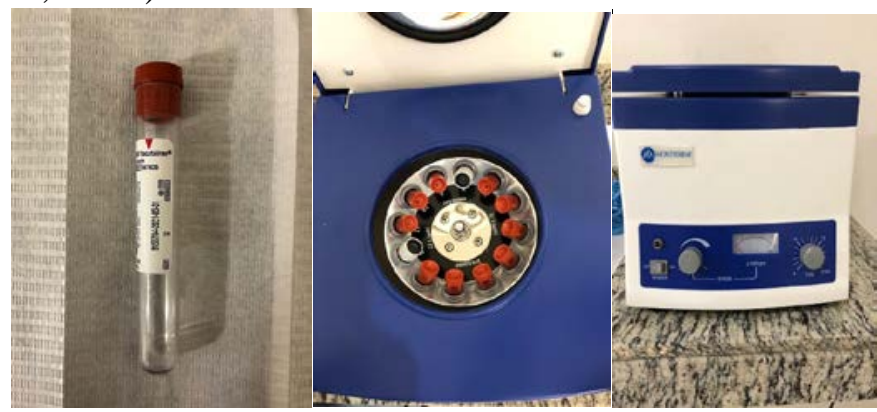

Figure 1: BD Vacutaine Serum Tube/Taken to MontSerrat Countertop/Centrifuge

Fibrin clots are then removed from the open tubes with sterile tweezers. Fibrin clots are separated from red blood cells, with the aid of tweezers and scissors (Figure 2).

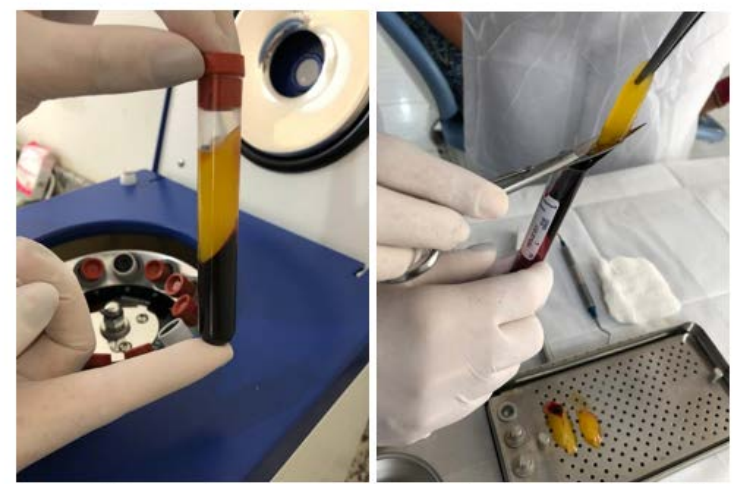

Figure 2: Processed tubes separated from fibrin clots of red blood cells

After separation of the clots, they are placed on the grille, covered with the tray and lid - material from the manufacturer MontSerrat. After 2 minutes the membranes will be ready for use (Figure 3).

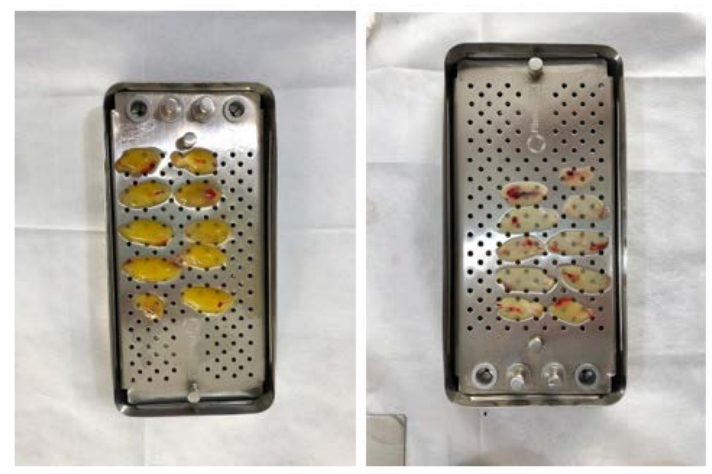

Figure 3: Clots on the grill before and after covered by the tray and lid. 
The studies have suggested different clinical applications for PRF, considered as a biomaterial of easy preparation, do not need to make anautogenous graft (Decreasing in some specific cases/ or potentiating them mainly with regard to soft tissue coverage), that is, it does not need another surgical site, has low cost, lower risk of infection because it is an autologous material, does not need anticoagulants and artificial additives such as bovine thrombin and calcium chloride (Pontel \& Boabaid, 2019; Shah et al., 2019). It is most often used in periodontal surgery procedures and with implants to improve regeneration and wound healing in soft tissues. Few studies are still focused on PRF regarding its biological actions, when compared to other platelet concentrates, however, the studies show beneficial effects, its disadvantages and its clinical applications (Hehn et al., 2016; Shah et al., 2019).

Since the regeneration of periodontal tissues is the focus of periodontal treatment, in order to restore the health, function and aesthetics of the periodontium. PRF specifically stimulates cell proliferation, induces cell proliferation of osteoblasts, periodontal ligament cells and growth factors, and suppresses the growth of oral epithelial cells (Miron et al., 2017). These cellspecific actions can be beneficial for periodontal regeneration. The treatment of complex cases of endo-perium lesions with PRF can be used as a plausible treatment alternative and to promote faster healing (elsherif, 2019). In some studies published in 2019,the use of PRF in periodontics may lead to an increase in the range of keratinized mucosa in the area of supported mucus prosthesis, in addition to root covering in cases of multiple gingival recession (De Angelis et al., 2019; Dutta et al., 2019; Frizzera et al., 2019; Miron et al., 2019).

\section{Conclusion}

The technique of using platelet-rich fibrin in dentistry has shown promising results, with low cost, easy execution and accelerated healing process. As limitations of the technique were found the short time to use the material and the small amount obtained after centrifugation.

\section{References:}

1. Carla, L., \& Fria, S. (2018). Uso de Fibrina Rica em Plaquetas ( PRF ) no tratamento de regeneração óssea ( ROG ) associado a osso autógeno e xenógeno . Relato de caso clínico.

2. De Angelis, P., De Angelis, S., Passarelli, P. C., Liguori, M. G., Manicone, P. F., \& D’Addona, A. (2019). Hard and Soft Tissue Evaluation of Different Socket Preservation Procedures Using Leukocyte and Platelet-Rich Fibrin: A Retrospective Clinical and 
Volumetric Analysis. Journal of Oral and Maxillofacial Surgery, 77(9), 1807-1815. https://doi.org/10.1016/j.joms.2019.05.004

3. Dutta, S., Nasim, F., \& Jana, D. (2019). Platelet Rich Fibrin : a Critical Review of the New Biomaterial. International Journal of Scientific Research, 8(12), 13-14.

4. elsherif, radwa. (2019). Clinical and Radiographic Assessment of Platelet Rich Fibrin Effect in One-Stage Dental Implant. Al-Azhar Dental Journal for Girls, 0(0), 0-0. https://doi.org/10.21608/adjg.2019.5227.1002

5. Frizzera, F., De Oliveira, G. J. P. L., Shibli, J. A., De Moraes, K. C., Marcantonio, E. B., \& Marcantonio, E. (2019). Treatment of periimplant soft tissue defects: A narrative review. Brazilian Oral Research, 33, e073.

https://doi.org/10.1590/1807-3107BOR-2019.VOL33.0073

6. Fursel, K. de A., Oliveira Neto, J. L. de, Sousa, M. J. de, Moreira, V. H. L. de O., \& Silveira, R. J. (2021). Propriedades da fibrina rica em plaquetas (PRF) aplicada a cirurgia oral - protocolo Choukroun. Research, Society and Development, 10(5), e59510515338. https://doi.org/10.33448/rsd-v10i5.15338

7. Gama Aires, C. C., De Figueiredo, E. L., Pereira, V. B. S., Vasconcellos, R. J. de H., Sabino, M. E., \& Medeiros, M. (2020). Terapias regenerativas em implantodontia: avanços no uso da Fibrina rica em plaquetas (PRF). Revista Eletrônica Acervo Saúde, 39, e2393. https://doi.org/10.25248/reas.e2393.2020

8. Godoy, P. A. I. (2013). Regeneração tecidual guiada em implantodontia: Revisão de literatura e relato de caso clínico. https://repositorio.unesp.br/bitstream/handle/11449/149517/0008571 22.pdf? sequence $=1$ \&isAllowed $=y$

9. Gupta, R., Luthra, R. P., \& Kaur, D. (2019). Various platelet-rich fibrin products and its applications: A review. International Journal of Applied Research, 5(3), 10-15.

10. Hak, S. (2020). L-PRF - Aplicação Clínica Em Implantodontia.

11. Hehn, J., Schwenk, T., Striegel, M., \& Schlee, M. (2016). The effect of PRF (platelet-rich fibrin) inserted with a split-flap technique on soft tissue thickening and initial marginal bone loss around implants: results of a randomized, controlled clinical trial. International Journal of Implant Dentistry, 2(1), 1-10. https://doi.org/10.1186/s40729-0160044-4

12. Kumar, Y. R., Mohanty, S., Verma, M., Kaur, R. R., Bhatia, P., Kumar, V. R., \& Chaudhary, Z. (2016). Platelet-rich fibrin: The benefits. British Journal of Oral and Maxillofacial Surgery, 54(1), 57-61. https://doi.org/10.1016/j.bjoms.2015.10.015 
13. Miron, R. J., Fujioka-Kobayashi, M., Bishara, M., Zhang, Y., Hernandez, M., \& Choukroun, J. (2017). Platelet-Rich Fibrin and Soft Tissue Wound Healing: A Systematic Review. Tissue Engineering Part B: Reviews, 23(1), 83-99.

https://doi.org/10.1089/ten.teb.2016.0233

14. Miron, R. J., Pinto, N. R., Quirynen, M., \& Ghanaati, S. (2019). Standardization of relative centrifugal forces in studies related to platelet-rich fibrin. Journal of Periodontology, 90(8), 817-820. https://doi.org/10.1002/JPER.18-0553

15. Oliveira, L., Buzzi, M., Leão, M., Andrade, P., \& Kuckelhaus, S. (2018). Ultrastructural morphological characterization of the autologous leuko-platelet fibrin matrix in association with xenogenic and alloplastic biomaterials for bone grafting. Fibrin ${ }^{\circledR}$ Protocol. Revista Catarinense de Implantodontia, 18, 24-33.

16. Pontel, C. Z., \& Boabaid, F. (2019). Regeneração tecidual guiada em recessões gengivais - o uso do enxerto gengival autógeno e das membranas de colágeno - uma revisão. Brazilian J Periodontol, 29(02), 51-59.

17. Rodrigues, G., Fabris, V., Mallmann, F., Rech, C. A., Carvalho, R. V., \& Ruschel, G. H. (2015). Fibrinas Ricas em Plaquetas, Uma Alternativa para Regeneração Tecidual: Revisão de Literatura. Journal of Oral Investigations, 4(2), 57-62. https://doi.org/10.18256/2238-510x/j.oralinvestigations.v4n2p57-62

18. Rossi, C. V. (2019). Regeneração Óssea Guiada Associada A Osso Xenógeno E Plasma Rico Em Fibrina: Relato De Caso Curitiba Regeneração Óssea Guiada Associada A Osso Xenógeno E Plasma Rico Em Fibrina: Relato De Caso.

19. Seidler, D. K. (2019). Avaliação Da Fibrina Rica Em Plaquetas Na Regeneração De Tecidos Orais: Uma Revisão De Literatura.

20. Shah, R., Gowda, T. M., Thomas, R., Kumar, T., \& Mehta, D. S. (2019). Biological activation of bone grafts using injectable plateletrich fibrin. Journal of Prosthetic Dentistry, 121(3), 391-393.

https://doi.org/10.1016/j.prosdent.2018.03.027

21. Zucchelli, G., Tavelli, L., McGuire, M. K., Rasperini, G., Feinberg, S. E., Wang, H. L., \& Giannobile, W. V. (2020). Autogenous soft tissue grafting for periodontal and peri-implant plastic surgical reconstruction. Journal of Periodontology, 91(1), 9-16.

https://doi.org/10.1002/JPER.19-0350 